\title{
Iodide-Selective Membrane Electrode Based on Salophen Complex of Cobalt (III)
}

\author{
Hamid R. Zare*, Farkhondeh Memarzadeh, Alireza Gorji and Mohammad Mazloum Ardakani
}

Department of Chemistry, Yazd University, Yazd, 89195-741, Iran

\begin{abstract}
Neste trabalho foi preparado um eletrodo altamente seletivo de membrana de PVC com o complexo cobalto-salofen. O sensor mostra uma sequiência seletiva anti-Hofmeister, com preferência por íons iodeto sobre vários anions comuns. O eletrodo apresentou uma dinâmica linear na faixa de $5,0 \times 10^{-7}$ a $1,0 \times 10^{-1} \mathrm{~mol} \mathrm{~L}^{-1}$, com uma inclinação Nernstiana de $-58,9 \mathrm{mV}$ com um limite de detecção de $3,0 \times 10^{-7} \mathrm{~mol} \mathrm{~L}^{-1}$. A região de $\mathrm{pH}$ de trabalho do sensor é de 3,1 a 9,8. A leitura rápida é de $15 \mathrm{~s}$, e tem uma vida útil de 2 meses. Os coeficientes de seletividade para o eletrodo proposto foram melhorados para alguns interferentes, se comparado com os eletrodos de membrana de iodeto disponíveis. O eletrodo proposto foi aplicado com sucesso na determinação direta de iodeto em sal comestível e como eletrodo indicador na titulação potenciométrica de $\mathrm{I}^{-}$contra $\mathrm{Ag}^{+}$.
\end{abstract}

\begin{abstract}
A highly selective PVC membrane electrode based on a cobalt-salophen complex was prepared. The sensor displays an anti-Hofmeister selectivity sequence with a preference for iodide ion over many common anions. The electrode has a linear dynamic range between $5.0 \times 10^{-7}$ to $1.0 \times 10^{-1} \mathrm{~mol} \mathrm{~L}^{-1}$, with a Nernstian slope of $-58.9 \mathrm{mV}$ decade ${ }^{-1}$ and a detection limit of $3.0 \times 10^{-7} \mathrm{~mol} \mathrm{~L}^{-1}$. The working $\mathrm{pH}$ range of the sensor is 3.1-9.8. It exhibits of a fast as $15 \mathrm{~s}$ and has a lifetime of about 2 months. The selectivity coefficients for the proposed electrode were improved for some interferences, when compared with those of available iodide membrane electrode. The proposed electrode was successfully applied for the direct determination of iodide in edible salt and as an indicator electrode in potentiometric titration of $\mathrm{I}^{-}$against $\mathrm{Ag}^{+}$.
\end{abstract}

Keywords: iodide ion-selective electrode, anti-Hofmeister, cobalt-salophen complex, potentiometry, anion sensor

\section{Introduction}

Potentiometric determination based on ion selective electrodes (ISEs) of minute quantities of ion species offers great advantages such as adaptable to small sample volume, speed and ease of preparation and procedures, relatively fast response, non-destructive, reasonable selectivity through judicious choice of the membrane active material, low cost, wide linear dynamic range and possible of on line monitoring. These characteristics have inevitably led to sensors ionic species, and the list of available electrode has grown substantially over the past year. ${ }^{1}$ However, the design of anion selective electrodes is far less advanced than the field of their cation counterparts. ${ }^{1,2}$ It has been proven difficult to control selectivity among anions, due to low charge to radii ratios, sensitivities to $\mathrm{pH}$ and high solvation energies. ${ }^{3,4}$

At first, anion selective membranes electrodes prepared with conventional ion exchangers such as quaternary

\footnotetext{
* e-mail: hrzare@yazduni.ac.ir
}

ammonium or phosphonium salts, ${ }^{5-7}$ which interact with the target anion through electrostatic attraction and induce a selectivity sequence governed by anion's enthalpy of hydration.

This results in a selectivity order very well known as the Hofmeister selectivity sequence ${ }^{8}$ (Organic ions $>\mathrm{ClO}_{4}^{-}>$ $\mathrm{SCN}^{-}>\mathrm{I}^{-}>\mathrm{Sal}^{-}>\mathrm{NO}_{3}^{-}>\mathrm{Br}^{-}>\mathrm{NO}_{2}^{-}>\mathrm{Cl}^{-}>\mathrm{HCO}_{3}^{-}>\mathrm{OAC}^{-}$ $>\mathrm{SO}_{4}^{2-}>\mathrm{HPO}_{4}^{2-}$ ) which reflects the order of decreasing hydrophobicity. ${ }^{9}$ A very interesting development in the field ISEs is the construction of electrodes that can chemically recognize specific anions and offer potentiometric responses that differ from classical anion exchanger-based membranes. One of the most important recognition elements that can be utilized in the development of anion-selective electrodes involves specific metal-ligand interactions. ${ }^{10}$ For the development of a truly anion-selective electrode, a relatively strong interaction between the ionophore and the anions is required in order to complex anions in a selective fashion. There are several literature reports on the anion selective electrode based on metalloporphyrins, ${ }^{11-13}$ 
metallophthalocyanines ${ }^{14-17}$ and some lipophilic organometallic compounds, ${ }^{17-23}$ which show anion selectivity in the membranes that differ from the Hofmeister selectivity sequence. The observed anti-Hofmeister behavior arises from a strong interaction between anions and the ionophores used. It has been show that the anion selectivity behavior of membrane electrodes based on different transition metal complexes is influenced by both the properties of the central metal ions and the structure of organic ligands. ${ }^{7,20,24-27}$ The salophen (N,N'-disalicylidene1,2-phenylendiamine dianion) as a polydentate ligand are well know to form very stable complexes with transition metal ions. ${ }^{28,29}$ However, very little is known about the use of their complexes as carrier in ion-selective electrodes. Recently, Amini et al. have reported cysteine-selective carbon paste electrode based on Cobalt (II) Salophen. ${ }^{30}$ Also, Wróblewski et al. prepared nitrite-selective ISE based on uranyl Salophen. ${ }^{31}$ Due to the important of selective iodide determination in different samples, especially in food and biological samples, varieties of ionophores have been used in the preparation of iodide ion-selective electrodes..$^{20,22,26-28,32-34}$ In recent years, we have reported new ion-selective membrane electrodes for $\mathrm{Pb}^{2+}, \mathrm{Ni}^{2+}$, and $\mathrm{Hg}^{2+}$ ions. ${ }^{35-37}$ The main aim of the present work was the development of a highly selective membrane electrode for iodide based on PVC membranes containing $\left[\mathrm{Co}^{\text {(III) }}\right.$ (salophen) (piperidine) ${ }_{2} \mathrm{ClO}_{4}$ complex $\left(\mathrm{CoSPPClO}_{4}\right)$, (Scheme 1) as a suitable sensing material. In the present study, the membrane compositions were optimized. Their optimum working conditions were investigated and interference studies have been made. The prepared membrane electrode displays a low detection limit and high selectivity and sensitivity to iodide determination.

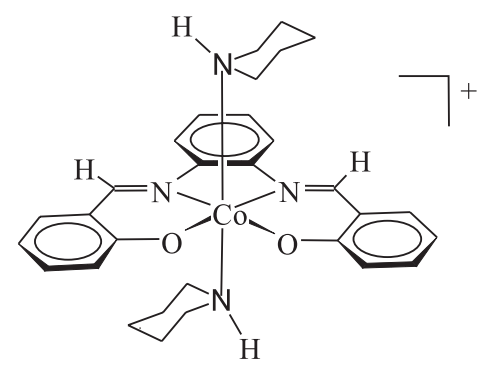

Scheme 1. $\left[\mathrm{Co}^{(\mathrm{III})}(\text { salophen })(\text { piperidine })_{2}\right]^{+}$.

\section{Experimental}

\section{Apparatus and reagents}

Potential measurements were made with a Metrohm ion analyzer model 691 at $25{ }^{\circ} \mathrm{C}$, by setting up the following assembly:
$\mathrm{Ag} / \mathrm{AgCl}, \mathrm{KCl}\left(3.0 \mathrm{~mol} \mathrm{~L}{ }^{-1}\right) /$ test solution/ membrane/KI $\left(1.0 \times 10^{-2} \mathrm{~mol} \mathrm{~L}^{-1}\right) / \mathrm{Ag}$

The steady-state potentials $( \pm 0.1 \mathrm{mV})$ were recorded relative to an Azarelectrode silver-silver chloride electrode containing $3.0 \mathrm{~mol} \mathrm{~L}^{-1}$ potassium chloride. Electronic absorption, UV-Vis, spectra were recorded on a Jasco spectrometer model 7800 .

$\left.\left[\mathrm{Co}^{(\mathrm{III})}(\text { salophen }) \text { (piperidine) }\right)_{2}\right] \mathrm{ClO}_{4}\left(\mathrm{CoSPPClO}_{4}\right)$, was prepared and purified as we described before. ${ }^{28}$ Poly(vinyl chloride) (PVC) of high molecular weight, Bis(2ethylhexyl) phthalate (BEHP), Dibutyl phthalate (DBP), Benzyl acetate (BA) and Acetophenone (AP) were used as received from Fluka. Tetrahydrofuran (THF), Hexadecyltrimethyl ammonium bromide (HTAB) and other chemicals were of the highest purity available from Merck and were used without further purification. All aqueous solutions were prepared with doubly distilled water.

\section{Electrode preparation}

All the membranes examined had the following composition: $30 \%$ of PVC, $59 \%$ of BEHP (as plasticizer), $5 \%$ of $\mathrm{CoSPPClO}_{4}$ (as ionophore) and $6 \%$ of HTAB (as additive), unless stated otherwise. The mixture of the components $(100 \mathrm{mg}$ ) was dissolved in $3.0 \mathrm{~mL}$ of THF. The resulting clear mixture was evaporated slowly until an oily concentrated mixture was obtained. A Pyrex tube ( $3.0 \mathrm{~mm}$ i.d.) was dipped into the mixture for a bout $5 \mathrm{~s}$, so that a nontransparent membrane is formed. The tube was then pulled out from the mixture and kept at room temperature for about $1 \mathrm{~h}$. The tube was then filled with an internal solution $\left(1.0 \times 10^{-2} \mathrm{~mol} \mathrm{~L}^{-1} \mathrm{KI}\right)$. The electrode was finally conditioned for $24 \mathrm{~h}$ by soaking in a $1.0 \times 10^{-2} \mathrm{~mol}$ $\mathrm{L}^{-1} \mathrm{KI}$ solution.

\section{Results and Discussion}

\section{Potential responses of the sensors}

In preliminary experiments, the $\mathrm{CoSPPClO}_{4}$ was used to prepare a PVC membrane ISE for a variety of anions. The potential response of the electrodes based on $\mathrm{CoSPPClO}_{4}$ for different anions are shown in Figure 1. As seen, except for $\mathrm{I}^{-}, \mathrm{SCN}^{-}, \mathrm{CN}^{-}$, and all other anions studied show a non-Nernstian response in the concentration range $1.0 \times 10^{-6}$ to $1.0 \times 10^{-1} \mathrm{~mol} \mathrm{~L}^{-1}$ due to their very weak interaction with the membrane. However, the electrode possesses much better sensitivity, response time and linear range for $\mathrm{I}^{-}$than for the $\mathrm{SCN}^{-}$and $\mathrm{CN}^{-}$ions. We therefore, studied in detail the properties of the electrode for iodide 
ion. As it is obvious from Figure 1, membrane electrode based on ionophore $\mathrm{CoSPPClO}_{4}$ gave selectivity patterns that deviate the Hofmeister series. Thus, the order of selectivity observed for the ionophore studied in this work was $\mathrm{I}^{-}>\mathrm{SCN}^{-}>\mathrm{CN}^{-}>\mathrm{NO}_{3}^{-}\left|\mathrm{ClO}_{4}^{-}>\mathrm{CO}_{3}^{2-}\right|$ other anions. This order of selectivity indicates that there is a selective interaction between the ionophore and all these anions. In the case of ionophores based on different metal ion complex, in addition to the electrostatic interaction between the central metal ion and analyte anions, there is a coordination action between both species involved. ${ }^{10-23}$ Thus, the selectivity sequence is dominated by both electrostatic and coordination forces and it is expected that both the nature of the complexed metal ion and the coordination ligand properties play important roles in determining the selectivity of the ionophore towards a specific anion. Recently, there have been a few reports on ionophores that when introduced into solvent polymeric membranes bring about iodide selectivity very divergent from the Hofmeister series. ${ }^{24,26-28,32-34}$

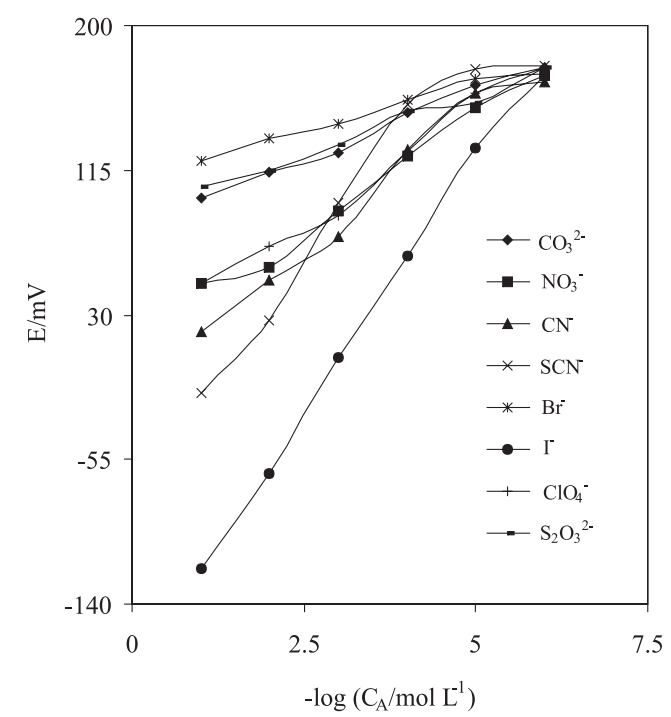

Figure 1. Potential response of various anion-selective electrodes based on ionophore $\mathrm{CoSPPClO}_{4}$.

To obtain a clue about the interaction mechanism of $\mathrm{CoSPPClO}_{4}$ with iodide, the UV-Vis. spectra of $1.0 \times 10^{-4}$ mol L-1 $\mathrm{CoSPPClO}_{4}$ in $\mathrm{CH}_{3} \mathrm{CN}$ were obtained with and without the presence of $1.0 \times 10^{-4} \mathrm{~mol} \mathrm{~L}^{-1}$ iodide and the results are shown in Figure 2. A comparison between the two spectra in Figure 2 reveals that the addition of I $\square$ to a $\mathrm{CoSPPClO}_{4}$ solution in $\mathrm{CH}_{3} \mathrm{CN}$ considerably increases the absorbance maxima of ionophore located at $364 \mathrm{~nm}$ and upon interaction with iodide ion, the peak of $\mathrm{CoSPPClO}_{4}$ located at $473 \mathrm{~nm}$ shift to lower wavelengths. The results suggested that the anti-Hofmeister behavior of the sensor can be explained by the observed specific interaction of iodide with the ionophore used and revealed that $\mathrm{CoSPPClO}_{4}$ could be used as a highly selective ionophore for the preparation of an iodide ion-selective electrode.

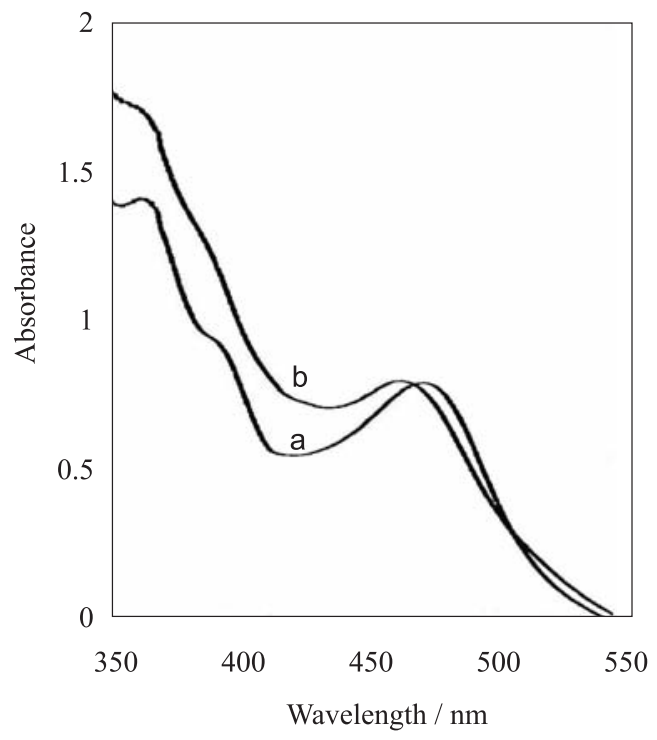

Figure 2. UV-Visible spectra of $1.0 \times 10^{-4} \mathrm{~mol} \mathrm{~L}^{-1} \mathrm{CoSPPClO}_{4}$ in $\mathrm{CH}_{3} \mathrm{CN}$ solution in the absence (a) and presence (b) of iodide.

\section{Effect of membrane composition}

Since the selectivity and sensitivity obtained for a given ionophore depends significantly on the membrane ingredients, nature of solvent mediators and additives used, we investigated the influence of membrane composition on the potential response of the iodide sensor. Table 1 presents the compositions of 11 different membranes along with other characteristics. The potential responses of all the membrane sensors were measured in the range of $1.0 \times$ $10^{-7}$ to $1.0 \times 10^{-1} \mathrm{~mol} \mathrm{~L}^{-1}$ iodide concentration for each 10 times of concentration change. As can be seen from Table 1, among the four different plasticizers used (i.e. BEHP, DBP, AP and BA), BEHP is a more effective solvent mediator than DBP, AP and BA in preparing the iodide ion-selective electrode (Nos. 5, 9-11). It should be noted that the nature of the plasticizer influences both the dielectric constant of the membrane and the mobility of the ionophore and its complex. ${ }^{32-37}$ The presence of lipophilic additives has a beneficial influence on the performance characteristics of the membrane electrode. Table 1 shows that, the addition of $6 \%$ HTAB will increase the slope of potential response of the sensor from a nonNernstian value of $20.6 \mathrm{mV}$ per decade ${ }^{-1}$ (No. 2) to a Nernstian value of $58.9 \mathrm{mV}$ per decade ${ }^{-1}$ (No. 5). The presence of such cationic additive can reduce ohmic resistance ${ }^{38}$ and improve the response behavior and selectivity of the membrane electrodes. ${ }^{39}$ Moreover, the 
Table 1. Composition of membranes and response characteristics of the electrodes

\begin{tabular}{|c|c|c|c|c|c|c|}
\hline \multirow{2}{*}{$\begin{array}{c}\text { Membrane } \\
\text { No. }\end{array}$} & \multicolumn{3}{|c|}{ Composition (\%) } & \multirow[b]{2}{*}{ Plasticizer } & \multirow{2}{*}{$\begin{array}{c}\text { Slope } \\
\left(\mathrm{mV} \text { decade }^{-1}\right)\end{array}$} & \multirow{2}{*}{$\begin{array}{c}\text { Linear range } \\
\left(\mathrm{mol} \mathrm{L}^{-1}\right)\end{array}$} \\
\hline & $\mathrm{CoSPPClO}_{4}$ & $\mathrm{PVC}$ & HTAB & & & \\
\hline 1 & - & 32 & 6 & $62(\mathrm{BEHP})$ & 8.7 & $10^{-6}-10^{-1}$ \\
\hline 2 & 5 & 33 & - & 62 (BEHP) & 20.6 & $10^{-6}-10^{-1}$ \\
\hline 3 & 7 & 30 & 3 & 60 (BEHP) & 30.0 & $10^{-6}-10^{-1}$ \\
\hline 4 & 6 & 30 & 4 & 60 (BEHP) & 45.7 & $10^{-6}-10^{-1}$ \\
\hline 5 & 5 & 30 & 6 & 59(BEHP) & 58.9 & $5 \times 10^{-7}-10^{-1}$ \\
\hline 6 & 5 & 25 & 6 & 64(BEHP) & 52.8 & $10^{-6}-10^{-1}$ \\
\hline 7 & 5 & 35 & 6 & 54(BEHP) & 51.7 & $10^{-6}-10^{-1}$ \\
\hline 8 & 5 & 20 & 6 & 69(BEHP) & 57.0 & $10^{-6}-10^{-1}$ \\
\hline 9 & 5 & 30 & 6 & $59(\mathrm{DBP})$ & 48.5 & $10^{-6}-10^{-1}$ \\
\hline 10 & 5 & 30 & 6 & $59(\mathrm{AP})$ & 45.3 & $10^{-5}-10^{-1}$ \\
\hline 11 & 5 & 30 & 6 & $59(\mathrm{BA})$ & 40.5 & $10^{-5}-10^{-1}$ \\
\hline
\end{tabular}

additives may catalyze the exchange kinetics at the samplemembrane interface. ${ }^{40}$ Further investigations were carried out to optimize the membrane ingredients by varying the amount of the ionophore. It is seen from Table 1 that membrane electrode with $5 \%$ of the ionophore (No. 5) has the best performance. As is obvious, the best response characteristics are obtained with a membrane composition of $59 \%$ BEHP, $30 \%$ PVC, $5 \% \mathrm{CoSPPClO}_{4}$ and $6 \% \mathrm{HTAB}$ (No. 5).

\section{Electrode response characteristics}

One of the ions present in aqueous solution is the hydrogen ion. It possible interferes with functioning of the sensor. In view of this, it is necessary to find the optimum $\mathrm{pH}$ range where the sensor functions without interference from the hydrogen ions. The influence of $\mathrm{pH}$ of the test solution on the potential response of the membrane sensor was tested over the range 2.6-11.1 at fixed concentration of $1.0 \times 10^{-3} \mathrm{~mol} \mathrm{~L}^{-1}$ iodide ions (Figure 3 ). The $\mathrm{pH}$ of the solutions was adjusted by the addition of $\mathrm{HNO}_{3}$ or $\mathrm{KOH}$. It is clear from Figure 3 that the useful $\mathrm{pH}$ range is 3.1-9.8 as the $\mathrm{pH}$ dependence of the electrode response was not significant in this range. However, the potential of the sensor was significantly affected below pH 3.1 and above $\mathrm{pH}$ 9.8. In the solution with $\mathrm{pH}>10.0$, the potentiometric response properties of the electrode slightly deteriorated and the observation can be explained by hydroxide-coordinated central metal interference.

For analytical applications the dynamic response time of a sensor is an important factor. Typical dynamic response of $\mathrm{CoSPPClO}_{4}$ membrane sensor for iodide ion is shown in Figure 4. In Figure 4a, the practical response time was recorded by changing solutions with different iodide concentrations. The measurements sequence was the low $\left(1.0 \times 10^{-6} \mathrm{~mol} \mathrm{~L}^{-1}\right)$ to the high $\left(1.0 \times 10^{-2} \mathrm{~mol} \mathrm{~L}^{-1}\right)$ concentrations. As can be seen, in whole the concentration

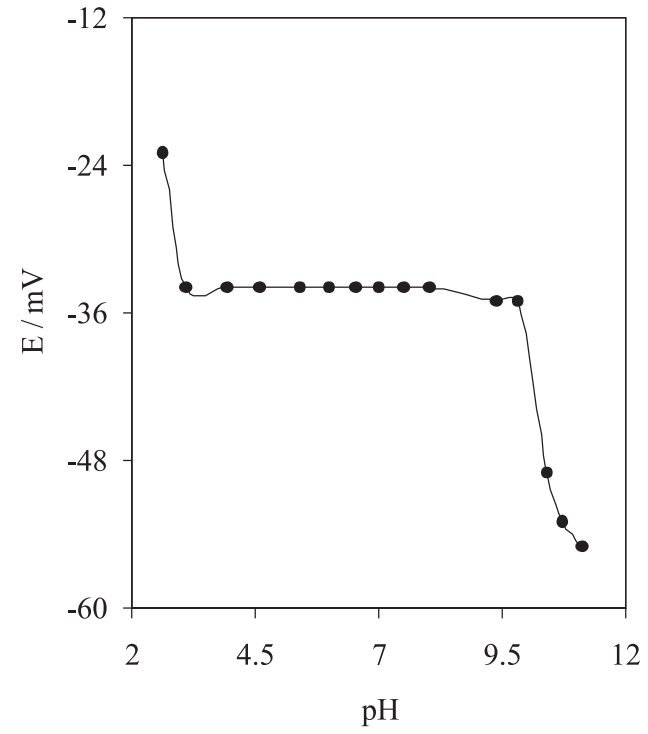

Figure 3. Effect of $\mathrm{pH}$ of the test solution $\left(1.0 \times 10^{-3} \mathrm{~mol} \mathrm{~L}^{-1}\right.$ of $\left.\mathrm{I}^{-}\right)$on the potential response of the $\mathrm{I}^{-}$ion-selective electrode.

range the electrode reaches the equilibrium response in a short time $(<15 \mathrm{~s})$. To evaluate the reversibility of the electrode, a similar procedure at the opposite direction was adopted. Figure $4 \mathrm{~b}$ shows the recorder tracings for a series of replicate concentration of iodide at concentrations ranging from $1.0 \times 10^{-1} \mathrm{~mol} \mathrm{~L}^{-1}$ to $1.0 \times 10^{-4}$ mol L-1. It is clear that the potentiometric response of the sensor was reversible, although the time needed to reach equilibrium values were longer than that for the low-tohigh sample concentrations.

The concentration of the internal KI solution in the electrode was changed from $1.0 \times 10^{-2}$ to $1.0 \times 10^{-4} \mathrm{~mol} \mathrm{~L}^{-1}$ and the potential response of the iodide selective electrode were measured. It was found that the variation of the concentration of the internal solution does not cause any significant difference in the potential response, except for an expected change in the intercept of the resulting Nernstian plots. A $1.0 \times 10^{-2} \mathrm{~mol} \mathrm{~L}^{-1} \mathrm{KI}$ solution was found quite 

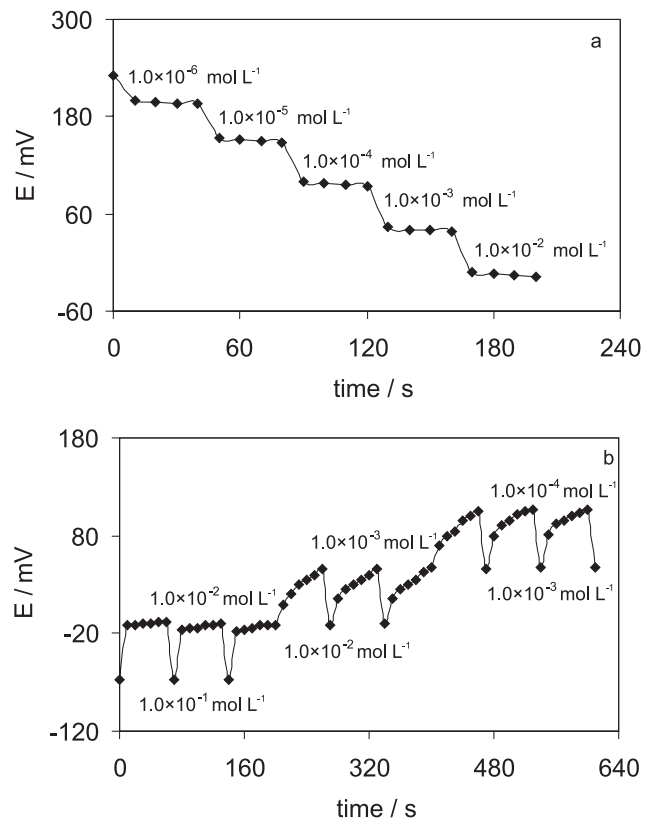

Figure 4. Potentiometric dynamic response of $\mathrm{CoSPPClO}_{4}$ membrane electrode for step changes of from (a) low-to-high and (b) high-to-low iodide concentrations.

appropriate for smooth functioning of the electrode system.

The optimum response of the electrode was tested after conditioning for different periods time in a $1.0 \times 10^{-2} \mathrm{~mol}$ $\mathrm{L}^{-1} \mathrm{KI}$ solution. The optimum equilibration time for the membrane electrode in the presence of a $1.0 \times 10^{-2} \mathrm{~mol} \mathrm{~L}^{-1}$ KI solution was $24 \mathrm{~h}$, after which it would generate stable potential in contact with iodide solutions. Using the optimized membrane composition and conditions described above, the potentiometric response of the most sensitive sensor system (No. 5) was studied in the iodide concentration range of $1.0 \times 10^{-7}$ to $5.0 \times 10^{-1} \mathrm{~mol} \mathrm{~L}^{-1}$. The emf values of the membrane sensor at varying concentration of iodide ion (Figure 5) indicate a rectilinear range from $5.0 \times 10^{-7}$ to $1.0 \times 10^{-1} \mathrm{~mol} \mathrm{~L}^{-1}$. The slope of the calibration curve was $-58.9 \mathrm{mV}$ per decade of $\mathrm{I}^{-}$ion concentration. The limit of detection, as determined from the intersection of the two extrapolated segments of the calibration graph,

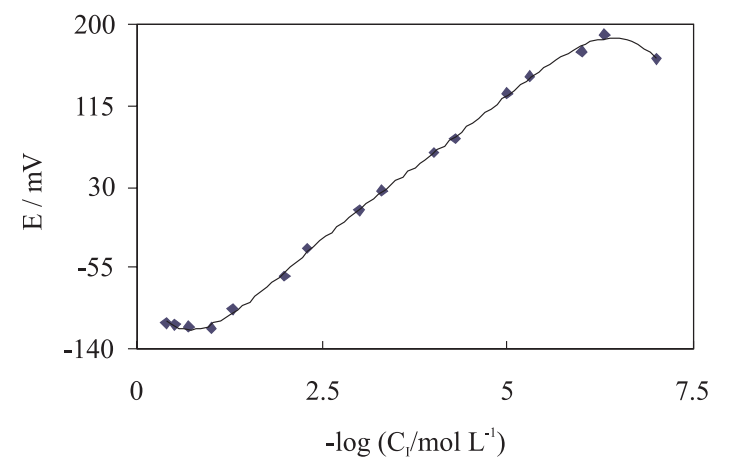

Figure 5. Calibration curve of iodide ion-selective electrode based on $\mathrm{CoSPPClO}_{4}$. was $3.0 \times 10^{-7} \mathrm{~mol} \mathrm{~L}^{-1}$. The standard deviation of the potential response for the membrane electrode dipped alternatively into solutions of $1.0 \times 10^{-2}, 1.0 \times 10^{-3}$ and $1.0 \times 10^{-4} \mathrm{~mol} \mathrm{~L}^{-1}$ of $\mathrm{I}^{-}$ion were $\pm 0.4, \pm 0.8$ and $\pm 1.2 \mathrm{mV}$ $(n=14)$. The electrodes prepared could be used for at least 2 months without any measurable divergence.

\section{Interference studies}

The most important characteristic of a membrane sensor is its response for primary ion in the presence of other anions in solution, which is usually expressed in terms of the potentiometric selectivity coefficient $\left(\mathrm{K}_{\mathrm{I}^{-}, \mathrm{A}^{\mathrm{n}}}^{\mathrm{Pot}}\right)$. The methods based on the Nicolsky-Eisenman equation for determining the potentiometric selectivity coefficient (e.g. the fixed primary method and the fixed interference method) suffer some limitations in terms of values for ions of unequal charges, non-Nernstian behavior of interfering ions and activity dependence of values. ${ }^{41,42}$ Thus, in this study, the recommended matched potential method $(\mathrm{MPM})^{41-43}$ which is totally independent of the NicolskyEisenman equation was used to overcome the abovementioned difficulties. According to this method, the selectivity coefficient is defined as the activity (concentration) ratio of the primary ion $\left(\mathrm{I}^{-}\right)$to the interfering ion $\left(\mathrm{A}^{\mathrm{n}-}\right), \mathrm{K}_{\mathrm{I}^{-}, \mathrm{A}^{\mathrm{n}-}}^{\text {Pot }}=\mathrm{a}_{\mathrm{I}^{-}} / \mathrm{a}_{\mathrm{A}^{\mathrm{n}-}}$, that give the same potential change in a reference solution potential. The experimental conditions employed and the resulting selectivity coefficients values are summarized in Table 2. The corresponding values reported for other $\mathrm{I}^{-}$ion-selective electrodes are also included in Table 2. The potentiometric selectivity patterns clearly indicate that the proposed sensor is highly selective toward iodide over a number of other anions. In Table 2, the analytical performance and selectivity coefficients for diverse anions of the proposed electrode are compared with the corresponding values previously reported for iodide ion-selective membrane electrodes. ${ }^{20,22,25-27,33,34,44,45}$ The data given in Table 2 indicate that, the selectivity coefficients, linear range, response time, $\mathrm{pH}$ range and slope of calibration graphs somewhat similar, in some case, or even superior, in most cases, to the sensors prepared previously. Therefore, on the basis of these data, we may conclude that the membrane sensor, proposed in this work is among the most selective and sensitive electrodes reported thus far for iodide ion.

\section{Practical application}

The proposed iodide membrane electrode (No. 5) was found to work well under laboratory conditions. It was applied successfully as an indicator electrode in the 
Table 2. Selectivity coefficient values $\left(\log \mathrm{K}_{\mathrm{I}^{\mathrm{P}}, \mathrm{A}^{\mathrm{F}}}^{\mathrm{Po}}\right)$ and potentiometric properties of $\mathrm{I}$ ion-selective electrode

\begin{tabular}{|c|c|c|c|c|c|c|c|c|c|c|}
\hline \multirow[t]{2}{*}{ Electrode characteristics } & \multicolumn{10}{|c|}{ References } \\
\hline & This work $^{\mathrm{a}}$ & $(20)$ & (22) & $(25)$ & (26) & $(27)$ & (33) & (34) & (44) & $(45)$ \\
\hline $\log \mathrm{K}\left(\mathrm{CN}^{-}\right)$ & -3.00 & - & - & - & - & - & - & - & -1.3 & - \\
\hline $\log \mathrm{K}\left(\mathrm{SCN}^{-}\right)$ & -3.30 & -2.1 & -2.3 & -1.67 & -2.7 & -0.05 & -3.1 & -2.1 & -0.92 & - \\
\hline $\log \mathrm{K}\left(\mathrm{ClO}_{4}^{-}\right)$ & -3.62 & -2.4 & -3.3 & -0.85 & -5.0 & -4.01 & -3.5 & -2.4 & -5.6 & - \\
\hline $\log \mathrm{K}\left(\mathrm{HCO}_{3}^{-}\right)$ & -3.73 & - & -3.1 & - & -4.8 & - & - & -4.2 & - & - \\
\hline $\log \mathrm{K}\left(\mathrm{Cl}^{-}\right)$ & -3.96 & -4.1 & -3.04 & -2.46 & -5.3 & -1.30 & -4.4 & -4.0 & -6.0 & -3.50 \\
\hline $\log \mathrm{K}\left(\mathrm{NO}_{3}^{-}\right)$ & -4.22 & -4.2 & -3.11 & -2.20 & -5.6 & -1.42 & -3.95 & -4.1 & -6.0 & - \\
\hline $\log \mathrm{K}\left(\mathrm{NO}_{2}^{-}\right)$ & -4.68 & -2.1 & -3.4 & -0.57 & -4.8 & -1.46 & -3.1 & -4.0 & -1.92 & - \\
\hline $\log \mathrm{K}\left(\mathrm{Br}^{-}\right)$ & -4.12 & -2.6 & -3.2 & -1.60 & -3.0 & -3.07 & -3.7 & -2.1 & -6.0 & -3.62 \\
\hline $\log \mathrm{K}\left(\mathrm{OAC}^{-}\right)$ & -4.82 & - & -3.92 & - & - & -2.78 & - & - & -1.62 & - \\
\hline $\log \mathrm{K}\left(\mathrm{S}_{2} \mathrm{O}_{3}^{-}\right)$ & -3.92 & - & -3.69 & - & - & - & - & - & - & - \\
\hline $\log \mathrm{K}\left(\mathrm{C}_{2} \mathrm{O}^{2-}\right)$ & -3.92 & - & -3.51 & - & - & - & - & - & - & - \\
\hline $\log \mathrm{K}\left(\mathrm{CO}_{3}^{2-}\right)$ & -4.52 & - & -3.15 & - & -4.9 & - & - & -4.3 & - & - \\
\hline $\log \mathrm{K}\left(\mathrm{SO}_{4}^{2-}\right)$ & -4.52 & -4.4 & -3.07 & - & - & - & - & -5.5 & - & -7.73 \\
\hline $\log \mathrm{K}$ (Ascorbat) & -3.22 & - & -3.13 & - & - & - & - & - & - & - \\
\hline $\log \mathrm{K}$ (Citrate) & -4.12 & - & -3.08 & - & - & - & - & - & - & - \\
\hline Slope $(\mathrm{mV} /$ decade $)$ & -58.9 & -55.8 & -57.5 & -57.8 & -59.7 & -59.0 & -55.7 & -58.7 & -71.0 & -54 \\
\hline Response time(s) & 15 & - & 7 & - & 60 & - & 40 & 10 & 15 & 300 \\
\hline Linear range (pA) & $1.0-6.3$ & $1.2-5.7$ & $1.3-5.1$ & $1.7-5.2$ & - & $1.0-4.5$ & $1.6-6.1$ & & $0.3-6.0$ & $1.0-6.0$ \\
\hline $\mathrm{pH}$ range & $3.1-9.8$ & - & $3.0-11.0$ & - & - & - & $4-8$ & - & $3.5-10$ & $2-12$ \\
\hline
\end{tabular}

${ }^{\mathrm{a}}$ Experimental conditions: Reference solution $\left(5.0 \times 10^{-7} \mathrm{~mol} \mathrm{~L}^{-1}\right.$ of $\left.\mathrm{I}^{-}\right)$, primary ion $\left(1.0 \times 10^{-5} \mathrm{~mol} \mathrm{~L}^{-1}\right.$ of $\left.\mathrm{I}^{-}\right)$, interfering ion $\left(1.0 \times 10^{-2}-6.6 \times 10^{-1} \mathrm{~mol}^{-1}\right.$ $\left.\mathrm{L}^{-1}\right)$.

potentiometric titration of $20 \mathrm{~mL}$ of $1.0 \times 10^{-4} \mathrm{~mol} \mathrm{~L}^{-1} \mathrm{KI}$ with $1.0 \times 10^{-2} \mathrm{~mol} \mathrm{~L}^{-1} \mathrm{AgNO}_{3}$ and the resulting titration curve are shown in Figure 6. As can be seen, the amount of iodide can be determined with electrode. To assess the applicability of the proposed electrode to real sample, an attempt was made to recovery of iodide in edible salt solutions. For this purpose, a new calibration graph has been prepared in a solution containing $3.5 \mathrm{~mol} \mathrm{~L}^{-1} \mathrm{NaCl}$ which is the concentration of edible salt when $20 \mathrm{~g}$ of it dissolved in 100

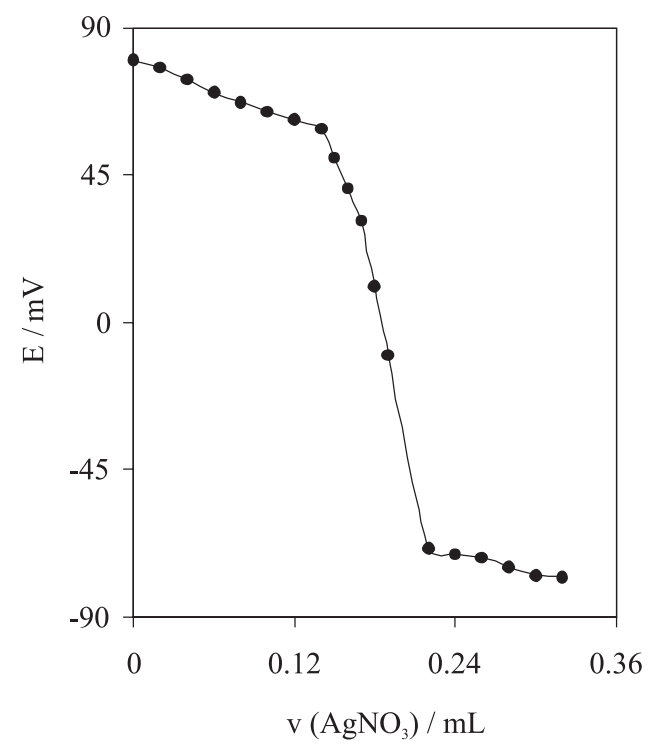

Figure 6. Application of the iodide membrane electrode for the potentiometric titration of $20.0 \mathrm{~mL}$ of $1.0 \times 10^{-4} \mathrm{~mol} \mathrm{~L}^{-1} \mathrm{KI}$ with $1.0 \times 10^{-2} \mathrm{~mol} \mathrm{~L}^{-1} \mathrm{AgNO}_{3}$.
$\mathrm{mL}$ water. This has to be done because of the very high concentration of chloride in edible salt. Then, $20 \mathrm{~g}$ of edible salt was dissolved in $100 \mathrm{~mL}$ of water and the potential measurements were made using the proposed electrode. The resulting data are shown in Table 3. Satisfactory recovery of the iodide ion added to edible salt samples was achieved without any prior treatment of the samples.

Table 3. Determination of iodide ion in edible salt samples

\begin{tabular}{ccc}
\hline $\mathrm{I}^{-}$added $\left(\mathrm{mol} \mathrm{L}^{-1}\right)$ & $\mathrm{I}^{-}$found $^{\mathrm{a}}\left(\mathrm{mol} \mathrm{L}^{-1}\right)$ & \% Recovery \\
\hline 0.0 & $(6.83 \pm 0.26) \times 10^{-5}$ & - \\
$6.80 \times 10^{-5}$ & $(1.33 \pm 0.05) \times 10^{-4}$ & 97.80 \\
$1.36 \times 10^{-4}$ & $(2.10 \pm 0.08) \times 10^{-4}$ & 102.94 \\
\hline
\end{tabular}

a average of four determination

\section{Conclusions}

A highly selective membrane electrode for iodide ions based on $\mathrm{CoSPPClO}_{4}$ as ionophore was investigated. The optimized formulation of the membrane (i.e. 59\% BEHP, $30 \% \mathrm{PVC}, 5 \% \mathrm{CoSPPClO} 4,6 \% \mathrm{HTAB}$ ) shows a linear concentration range of $5.0 \times 10^{-7}$ to $1.0 \times 10^{-1} \mathrm{~mol} \mathrm{~L}^{-1}$ with a slope of $-58.9 \mathrm{mV}$ per decade and limit of detection of $3.0 \times 10^{-7} \mathrm{~mol} \mathrm{~L}^{-1}$. The selectivity coefficient data for iodide ion relative to most of interfering ions are negligibly small. The electrode has a fast response time and good reproducibility. The analytical applications of the proposed electrode were successfully checked. 


\section{References}

1. Bühlmann, P.; Pretsh, E.; Bakker, E.; Chem. Rev. 1998, 98, 1593.

2. Schmidtchen, F.P.; Berger, M.; Chem. Rev. 1997, 97, 1609.

3. Beerand, P.D.; Gale, P.A.; Angew. Chem. Int. Ed. 2001, 40, 486.

4. Dietrich, B.; Pure Appl. Chem. 1993, 65, 1457.

5. Arnold, M.A.; Solsky, R.L.; Anal. Chem. 1986, 58, 84R.

6. Yu, R.Q.; Ion Selective Electrode Rev. 1986, 3, 153.

7. Wotring, V.J.; Johnson, D.M.; Bachas, L.G.; Anal. Chem. 1990, 62, 1506.

8. Wuthier, U.; Pham, H.V.; Zund, R.; Welti, D.; Funck, R.J.J.; Bezegh, A.; Ammann, D.; Pretsch, E.; Simon,V.; Anal. Chem. 1984, 56, 535 .

9. Schulthess, P.; Ammann, D.; Krautler, B.; Caderas, C.; Stepane, K.R.; Simon, W.; Anal. Chem. 1985, 57, 1397.

10. Hutchins, R.S.; Bachas, L.G.; Anal. Chem. 1995, 67, 1654.

11. Ammann, D.; Huster, M.; Kräutler, B.; Rusterholz, B.; Schulthess, P.; Lindemann, B.; Halder, E.; Simon, W.; Helv. Chim. Acta 1986, 69, 8749.

12. Chang, Q.; Meyerhoff, M.E.; Anal. Chim. Acta 1986, 186, 81.

13. Hodinar, A.; Jyo, A.; Anal. Chem. 1989, 61, 1169.

14. Lui, J.; Masuda, Y.; Sekido, E.; Wakida, S.; Hiiro, K.; Anal. Chim. Acta 1989, 224, 1145.

15. Liu, I.; Masuda, Y.; Sekido, E.; J. Electroanal. Chem. 1990, $291,67$.

16. Tse, Y.H.; Janda, P.; Lever, A.B.P.; Anal. Chem. 1994, 66, 384.

17. Allen, J.R.; Florido, A.; Young, S.D.; Daunert, S.; Bachas, L.G.; Electroanalysis 1995, 7, 710.

18. Wathier, U.; Ammann, D.; Pretsch, E.; Simon, W.; Anal. Chem. 1984, 56, 535 .

19. Shamsipur, M.; Khayatan, G.; Tangestaninejad, S.; Electroanalysis 1999, 11, 1340.

20. Yuan, R.; Chai, Y.-Q.; Liu, D.; Gao, D.; Li, J.-Z.; Yu, R.-Q.; Anal. Chem. 1993, 65, 2572.

21. Florido, A.; Bachas, L.G.; Valiente, M.; Yillascusa, I.; Analyst 1994, 119, 2421.

22. Ganjali, M.R.; Poursaberi, T.; Hosseini, M.; Salavati-Niasary, M.; Yousefi, M.; Shamsipur, M.; Anal. Sci. 2002, 18, 289.

23. Liu, D.; Chen, W.C.; Shen, G.L.; Yu, R.Q.; Analyst 1996, 121, 1495 .

24. Ying, M.; Yuan, R.; Zhang, X.-M.; Song, Y.-Q.; Li, Z.-Q.; Shen, G.-L.; Yu, R.-Q.; Analyst 1997, 122, 1143.
25. Li, Z.-Q.; Yuan, R.; Ying, H.; Song, Y.-Q.; Shen, G.L.; Yu, R.Q.; Anal. Lett. 1997, 30, 1455.

26. El Aamrani, F.Z.; Garcia-Raurich,V.; Sastre, A.; Beyer, L.; Florido, A.; Anal. Chim. Acta 1999, 402, 129.

27. Shamsipur, M.; Sadeghi, S.; Naeimi, H.; Sharghi, H.; Polish J. Chem. 2000, 74, 231.

28. Amirnasr, M.; Schenk, K.J.; Gorji, A.; Vafazadeh, R.; Polyhedron 2001, 20, 695.

29. Verboom, W.; Rudkevich, D.M.; Reinhoudt, D.N.; Pure Appl. Chem. 1994, 66, 679.

30. Amini, M.K.; Khorasani, J.H.; Khaloo, S.S.; Tangestaninejad, S.; Anal. Biochem. 2003, 320, 32.

31. Wróblewski, W.; Brzózka, Z.; Rudkevich, D.M.; Reinhoudt, D.N.; Sens. Actuators B 1996, 37, 151.

32. Coetzee, C.J.; Freser, H.; Anal. Chem. 1969, 41, 1128.

33. Yuan, R.; Song, Y.; Chai, Y.Q.; Xia, S.X.; Zhong, Q.Y.; Yi, B.; Ying, M.; Shen, G.; Yu, R.; Talanta 1999, 48, 649.

34. El Aamrani, F.Z.; Sastre, A.; Aguilar, M.; Beyer, L.; Florido, A.; Anal. Chim. Acta 1996, 329, 247.

35. Amini, M.K.; Mazloum, M.; Ensafi, A.A.; Fresenius J. Anal Chem. 1999, 364, 690.

36. Mazloum, M.; Salavati-Niassary, M.; Amini, M.K.; Sens. Actuators B 2002, 82, 259.

37. Mazloum, M.; Amini, M.K.; Mohammadpoor-Baltork, I.; Sens. Actuators B 2000, 63, 80.

38. Ammann, D.; Pretsch, E.; Simon, W.; Lindner, E.; Bezegh, A.; Pungor, E.; Anal. Chim. Acta 1985, 171, 119.

39. Rosatzin, T.; Bekker, E.; Suzuki, K.; Simon, W.; Anal. Chim. Acta 1993, 280, 197.

40. Gering, P.M.; Morf, W.E.; Welti, M.; Pretsch, E.; Simon, W.; Helv. Chim. Acta 1990, 73, 203.

41. Umezawa, Y.; Umezawa, K.; Sato, H.; Pure Appl. Chem. 1995, 67, 507.

42. Bakker, E.; Electroanalysis 1997, 9, 7.

43. Gadzekpo, V.P.Y.; Christian, G.D.; Anal. Chim. Acta 1984, 164, 279.

44. Shamsipur, M.; Soleymanpour, A.; Akhond, M.; Sharghi, H.; Naseri, M.A.; Anal. Chim. Acta 2001, 450, 37.

45. Somer, G.; Kalayci, S.; Ekmekci, G.; Sens. Actuators B 2001, 81,122 .

Received: April 30, 2004 Published on the web: March 9, 2005 